\title{
Pharmacologic Treatment of COVID-19: Evidence-Based Update
}

\author{
Jose Chacko', Muhammed Unais ${ }^{2}$ \\ 'Senior Consultant, Critical Care, ${ }^{2}$ Respiratory Therapist, Majumdar Shaw Medical Center, Bangalore, Karnataka, India
}

\section{Abstract}

The COVID-19 pandemic continues to pose challenges on an unprecedented scale to health-care systems across the world. Mortality from COVID-19 remains low, and survival has improved compared to the early stages of the pandemic. Several new and repurposed therapeutic modalities continue to emerge as a part of our armamentarium to combat the damage triggered by the Severe Acute Respiratory Syndrome Coronavirus-2 virus. It is unclear if the more favorable clinical outcomes are attributable to specific pharmacological agents or improved care overall, as health-care systems attain increasing experience with a complex disease process. This review aims to provide an updated review of various pharmacological therapies that have been evaluated in the treatment of COVID-19 infection.

Keywords: Antiviral agents, COVID-19 pandemic, interleukin inhibitors, pharmacotherapy, steroids

\section{INTRODUCTION}

The COVID-19 pandemic continues to pose challenges on an unprecedented scale to health-care systems across the world. Mortality from COVID-19 remains low, and survival has improved compared to the early stages of the pandemic. Several new and repurposed therapeutic modalities continue to emerge as a part of our armamentarium to combat the damage triggered by the Severe Acute Respiratory Syndrome Coronavirus-2 (SARS-CoV-2) virus. It is unclear if the more favorable clinical outcomes are attributable to specific pharmacological agents or improved care overall, as health-care systems attain increasing experience with a complex disease process. This review aims to provide an updated review of various pharmacological therapies that have been evaluated in the treatment of COVID-19 infection.

\section{Antiviral Agents}

\section{Remdesivir}

Remdesivir has been previously used in Ebola virus infection, with limited evidence of efficacy. ${ }^{[1]}$ It was used in the first case of COVID-19 infection reported from the United States on January 9, 2020. ${ }^{[2]}$ Initial experience with remdesivir in COVID-19 involved its use among passengers of the Diamond Princess cruise ship that returned to the United States from Japan. ${ }^{[3]}$ Several randomized controlled trials (RCTs) have evaluated the efficacy of remdesivir in patients with COVID-19 infection.

\begin{tabular}{|l|l|}
\hline \multicolumn{3}{|c|}{ Access this article online } \\
\hline Quick Response Code: & Website: \\
\hline & www.ijrc.in \\
\hline
\end{tabular}

The ACTT-1 RCT studied hospitalized COVID-19 patients with the involvement of the lower respiratory tract. ${ }^{[4]}$ In the intervention arm, a loading dose of remdesivir, $200 \mathrm{mg}$ intravenously, was administered on day 1 , followed by $100 \mathrm{mg}$ daily for 9 days; the control arm received placebo. Early unblinding of the results was carried out on the recommendation of the data and safety monitoring board after preliminary results were available on 1059 patients. The primary outcome, the time to hospital discharge or requirement for hospitalization as a part of infection control alone, was 11 days (95\% confidence interval [CI]: 9-12) in the remdesivir arm compared with 15 days (CI: 13-19) in the placebo arm. Although the mortality at 14 days was lower with remdesivir, the difference was not statistically significant (hazard ratio: $0.7 ; 95 \%$ CI: $0.47-1.04$ ). The incidence of serious adverse events was not different between groups.

Spinner et al. conducted an open-label RCT with a 10-day versus 5-day course of remdesivir compared to standard care alone in a 1:1:1 ratio. ${ }^{[5]}$ Patients had moderate disease with lung infiltrates on radiological imaging and oxygen saturation of $>94 \%$ on room air. Remdesivir was administered intravenously in a dose of $200 \mathrm{mg}$ on day 1 , followed by $100 \mathrm{mg}$ on subsequent days.

Address for correspondence: Dr. Jose Chacko Senior Consultant, Critical Care, Majumdar Shaw Medical Center, Bangalore,Karnataka, India. E-mail: chackojose@gmail.com

This is an open access journal, and articles are distributed under the terms of the Creative Commons Attribution-NonCommercial-ShareAlike 4.0 License, which allows others to remix, tweak, and build upon the work non-commercially, as long as appropriate credit is given and the new creations are licensed under the identical terms.

For reprints contact: WKHLRPMedknow_reprints@wolterskluwer.com

How to cite this article: Chacko J, Unais M. Pharmacologic treatment of COVID-19: Evidence-based update. Indian J Respir Care 2021;10:S34-8.

Received: $30-10-2020$

Accepted: 09-03-2021 Published: 29-04-2021 
The primary outcome, the clinical status on day 11, was assessed on a 7 -point ordinal scale $(1=$ death and $7=$ discharge $)$. Patients randomized to receive a 5-day course of treatment had a more favorable clinical status on day 11 compared to standard care alone (odds ratio: 1.65 ; CI: 1.09-2.48). There was no significant difference in the clinical status on day 11 between the 5-day versus 10-day treatment groups.

The WHO Solidarity trial including 11,266 adults was carried out at 405 hospitals across 30 countries. ${ }^{[6]}$ They evaluated the efficacy of four drugs, including remdesivir, hydroxychloroquine, lopinavir, and interferon beta-1a. There were four paired comparisons for each drug and its control. In the remdesivir arm of the study, 2743 patients received remdesivir, while 2708 patients were included in the control arm. In-hospital mortality, the primary outcome was not different between remdesivir and the control groups (rate ratio [RR] for mortality: $0.95 ; 95 \%$ CI: $0.81-1.11$; $P=0.50)$. There was no difference between groups in the requirement for mechanical ventilation or the time to hospital discharge. The other three drugs studied, hydroxychloroquine, lopinavir, and interferon beta-1a, were also found to have no significant impact on these clinical outcomes.

Where do we stand with regard to the treatment of COVID-19 with remdesivir in light of the contrasting evidence? In mild to moderate disease with no requirement for respiratory support, remdesivir does not seem to impact clinical outcomes. At best, it may shorten the time to recovery if administered early in the course of illness (within the first 10 days) to patients who are at risk for hyperinflammation. However, identifying those who might benefit from remdesivir may not be an easy task in the real world.

\section{Remdesivir combined with baricitinib}

Baricitinib is a selective inhibitor of Janus kinase (JAK) 1 and 2, with immunomodulatory properties. It exerts anti-inflammatory effects by blockade of multiple pro-inflammatory cytokines. Kalil et al. compared the combination of remdesivir and baricitinib with remdesivir and placebo in a RCT among hospitalized adult patients with COVID-19. ${ }^{[7]}$ Remdesivir was administered for 10 days and baricitinib or placebo for 14 days. The median time to recovery assessed by an ordinal scale was significantly lower with baricitinib compared to placebo ( 7 vs. 8 days; RR for recovery, 1.16; 95\% CI, 1.01-1.32; $P=0.03$ ). The treatment effect was particularly prominent among patients who were on high-flow oxygen or noninvasive ventilation at the time of enrolment. This study offers promise regarding the efficacy of baricitinib in COVID-19 through JAK1 and JAK2 inhibition with blockade of the immune cascade and inhibition of viral replication.

\section{Favipiravir}

An RNA-dependent RNA-polymerase inhibitor, favipiravir is administered enterally and approved for the treatment of novel outbreaks of influenza in Japan and specifically for COVID-19 in Russia. A pilot study was conducted across six centers in Russia to assess the efficacy and safety of favipiravir. ${ }^{[8]}$ In this three-armed study, favipiravir was administered in doses of $1.6 \mathrm{~g}$ twice daily, followed by $600 \mathrm{mg}$ twice daily or $1.8 \mathrm{~g}$ twice daily followed by $800 \mathrm{mg}$ twice daily for a total duration of 14 days and compared to standard care in moderate disease. Viral clearance was significantly greater by day 5 in favipiravir-treated patients compared to standard care alone $(62.5 \%$ vs. $30 \% ; P=0.018)$. However, by day 10 , there was no significant difference in viral clearance between patients who received favipiravir compared to standard care. The median time to resolution of fever was significantly less with favipiravir compared to standard care. There was no difference between groups in the degree of resolution of changes on chest computed tomography by day $15 .{ }^{[7]}$ An ongoing phase 2 trial is currently evaluating the efficacy of favipiravir as prophylaxis in long-term care facilities that have experienced outbreaks of COVID-19. ${ }^{[9]}$ Based on currently available evidence, the efficacy of favipiravir in COVID-19 remains uncertain.

\section{Ivermectin}

An antiparasitic drug, ivermectin, has exhibited in vitro activity against a broad range of viruses. In an experimental study from Victoria, Australia, ivermectin demonstrated a 93\% reduction in viral RNA in Vero-hSLAM cell lines at $24 \mathrm{~h}$ of treatment. By $48 \mathrm{~h}$, nearly all viral material was effectively eliminated. ${ }^{[10]}$ However, the drug concentration used was much higher than the levels attainable with a usual oral dose. Pharmacokinetic data from studies using higher doses suggest inhibitory concentrations are probably not achievable in the clinical setting. ${ }^{[1]}$ In an RCT that compared ivermectin $300 \mathrm{mcg} / \mathrm{kg} /$ day with placebo for 5 days, the median time to resolution of symptoms was not different between groups. ${ }^{[12]}$ Although in widespread use in many parts of the world, including India, there is currently no evidence to support a beneficial effect with ivermectin use in COVID-19 infection.

\section{Hydroxychloroquine}

Hydroxychloroquine exhibits antiviral effects in vitro; ${ }^{[13]}$ however, several controlled trials ${ }^{[14,15]}$ and meta-analyses ${ }^{[16,17]}$ have failed to reveal clinical benefit with its use in COVID-19. It is currently not recommended as a therapeutic option in patients with COVID-19 infection.

\section{INTERLEUKIN INHIBITORS}

The cytokine storm, due to a dysregulated host response, has captured the attention of mainstream and scientific media, considering its possible role leading to poor outcomes in COVID-19. Several mediators, including chemokines, interleukins (IL), interferons, and tumor necrosis factor, are released during the course of infection. This innate response, commonly observed in bacterial and viral infections, is aimed to eliminate the causative pathogen. However, a dysregulated response can cause injury to the host. A profound inflammatory response occurs in the lung; this may interfere with gas exchange, leading to hypoxemia, an important cause of mortality. Several drugs commonly used in chronic inflammatory diseases have been proposed as inhibitors of the exaggerated immune response in an attempt to improve clinical outcomes in COVID-19. 
Chacko and Unais: Pharmacologic treatment of COVID-19

\section{Tocilizumab}

Among the key cytokine inhibitors that have been evaluated in COVID-19, IL-6 blockers, including tocilizumab and sarilumab, have been the focus of interest. An earlier randomized phase 3 controlled trial revealed no improvement in clinical status with the use of tocilizumab; besides, there was no significant difference in the 4-week mortality, one of the secondary end points. ${ }^{[18]}$ Following this study, the REMAP-CAP and RECOVERY trials reported improved survival among selected patient populations with COVID-19.

The REMAP-CAP trial enrolled patients with COVID-19 who required respiratory support within $24 \mathrm{~h}$ of admission to the intensive care unit. ${ }^{[19]}$ Three hundred and fifty-three patients were randomized to the tocilizumab arm, while 402 patients were included in the control group. Combination therapy with corticosteroids was administered in $92.7 \%$ of patients in the tocilizumab arm and $93.9 \%$ of patients in the control group. Tocilizumab administration resulted in an increase in the number of organ support-free days, less time to discharge from hospital, and reduced in-hospital mortality.

In the RECOVERY trial, patients with hypoxia and systemic inflammation with C-reactive protein level $>75 \mathrm{mg} / \mathrm{l}$ were randomized to receive tocilizumab 400-800 mg intravenously, followed by a second dose in $12-24 \mathrm{~h}$ if no clinical improvement was observed. Tocilizumab use was associated with a significantly lower all-cause mortality at 28 days (29\% vs. 33\%, relative risk: 0.86 ; 95\% CI: $0.77-0.96)$. On subgroup analysis, the mortality benefit was confined to patients who had combined treatment with corticosteroids. ${ }^{[20]}$

\section{Interleukin-1 blockers}

There are limited data with the use of specific IL-1 blockers in COVID-19. Anakinra, an IL-1 blocker, has been evaluated in preliminary trials. It was found to be safe and appeared to result in a more rapid clinical improvement among a small series of 29 patients. ${ }^{[21]}$ Anakinra $100 \mathrm{mg}$ twice daily for 3 days, followed by once daily for 7 days was administered in 52 patients in another study. These patients were compared to a retrospective control group of 44 patients. Anakinra administration reduced the need for invasive mechanical ventilation and improved survival without adverse effects. ${ }^{[22]}$

Although it might seem intuitive, historically, cytokine blocker therapy has revealed a track record of failure in both bacterial and viral infections. A major stumbling block has been to identify the optimal time of administration. Considering the lacunae in our current state of knowledge, it is nearly impossible to identify the point at which the host response spirals out of control to facilitate the effective timing of therapy. The host immune response clearly revolves around a complex interplay of several mediators; the response is likely to be neither linear nor uniform. Besides, the prolonged duration of action of cytokine inhibitors commonly used in chronic inflammatory disorders may cause superinfections in critically ill patients. Furthermore, targeting a single cytokine such as IL-6 is may not always be beneficial, considering that it may not be the sole driver of the adaptive response. The promise shown in these early studies needs corroboration in larger studies.

\section{Corticosteroids}

The RECOVERY trial was designed to assess the efficacy of several treatment modalities in COVID-19 and included more than 11,000 patients from 175 centers of the National Health Services in the UK. ${ }^{[23]}$ Hospitalized patients with clinically suspected or laboratory-confirmed COVID-19 infection were eligible for inclusion in the study. Patients were randomized in a 2:1 ratio and received dexamethasone $6 \mathrm{mg}$ once daily IV or orally for a maximum of 10 days or usual care alone. ${ }^{[24]}$ The overall mortality at 28 days was significantly lower in dexamethasone-treated patients compared to standard care alone (21.6\% vs. $24.6 \%$; RR: 0.83, CI: $0.74-0.92, P<0.001)$. The 28-day mortality was highest in patients who were invasively ventilated (40.7\%) compared to those who received supplemental oxygen alone $(25 \%)$ and those who did not require respiratory support $(13.2 \%)$ at randomization. The reduction in mortality was highest in patients who were on invasive mechanical ventilation; dexamethasone resulted in a reduction in mortality by $35 \%$ among this subgroup of patients (RR $0.65 ; 95 \%$ CI: $0.51-0.82 ; P<0.001$ ). A $20 \%$ reduction in mortality was noted in patients who received supplemental oxygen alone or combined with noninvasive ventilation (RR $0.80 ; 95 \% \mathrm{CI}: 0.70-0.92 ; P=0.002$ ). Interestingly, no difference in 28-day mortality was observed with dexamethasone treatment in patients who did not require supplemental oxygen or respiratory support.

Among the secondary outcomes, in the dexamethasone group, a statistically significant reduction in the duration of hospitalization (median: 12 vs. 13 days) was observed, although the difference may not be clinically meaningful. Besides, a higher proportion of patients could be discharged within 28 days. Among patients who did not receive invasive ventilation at enrolment, significantly fewer patients worsened to the composite end point of invasive mechanical ventilation or death with dexamethasone treatment. Although the study was conducted against a background of extremely challenging circumstances, the RECOVERY trial offers robust evidence regarding the efficacy of dexamethasone in reducing mortality among hospitalized patients with COVID-19.

In the REMAP-CAP RCT, intravenous hydrocortisone was evaluated in patients with severe COVID-19. ${ }^{[25]}$ The trial was stopped early following the press release of the RECOVERY trial that revealed improved survival with dexamethasone. Although underpowered due to early cessation, Bayesian modeling revealed a $93 \%$ and $80 \%$ probability of improvement in organ support-free days at 21 days for the fixed duration and the shock-dependent course, respectively. This study adds to the body of evidence that suggests improved clinical outcomes with low-dose corticosteroids in COVID-19. 
Chacko and Unais: Pharmacologic treatment of COVID-19

\section{Convalescent Plasma}

Most patients who recover from SARS-CoV-2 infection develop antibodies to viral proteins within 2-3 weeks following infection. Quantitative assays can detect the presence of neutralizing antibodies. Convalescent plasma obtained from patients who have recovered from COVID-19 was considered to be a possible therapeutic option during the early phase of the pandemic.

In an early Chinese trial, patients with severe COVID-19 infection, characterized by tachypnea $>30 / \mathrm{min}$, oxygen saturation of $\leq 93 \%$ on room air or $\mathrm{PaO}_{2} / \mathrm{FiO}_{2}$ ratio of $\leq 300 \mathrm{~mm} \mathrm{Hg}$, or life-threatening disease characterized by the requirement for mechanical ventilation, shock or extrapulmonary organ failure were studied. ${ }^{[26]}$ The administration of convalescent plasma resulted in more rapid viral clearance at $72 \mathrm{~h}(87 \%$ vs. $38 \%)$. No statistically significant difference was noted between plasma-treated patients and those who received standard care regarding clinical improvement assessed using a 6-point severity scale or mortality at 28 days. A subsequent observational study of 35,322 patients suggested that convalescent plasma transfusion within 3 days of diagnosis was associated with lower mortality at 7 and 30 days compared to later transfusion. ${ }^{[27]}$ However, more recent RCTs have questioned the usefulness of convalescent plasma in COVID-19 infection.
The PLACID study was conducted by the Indian Council of Medical Research across 39 tertiary care hospitals in India ${ }^{[28]}$ In this RCT, 464 adult patients with moderately severe COVID-19 infection were assigned to receive two units of $200 \mathrm{ml}$ each of convalescent plasma, administered at a 24-h interval and compared to a control group. This study did not show any difference between groups in the progression to severe disease or all-cause mortality at 28 days.

In a multicentric RCT from Argentina, convalescent plasma was administered to hospitalized patients with severe COVID-19 pneumonia in a 2:1 study design. ${ }^{[29]}$ Two hundred and twenty-eight patients were assigned to the convalescent plasma group and 105 to the placebo arm. There was no significant difference noted between groups at 30 days in clinical outcomes based on an ordinal scale. The overall mortality was also not different between groups $-10.96 \%$ in the convalescent plasma arm and 11.43 in the control arm.

Table 1 provides a brief summary of the studies that have demonstrated efficacy in the treatment of COVID-19.

\section{Conclusions}

The COVID-19 pandemic has led to extensive research to evaluate the efficacy of new and repurposed drugs. There are several ongoing trials as scientific evidence continues to

Table 1: Summary of studies that have demonstrated efficacy in the treatment of COVID-19

\begin{tabular}{|c|c|c|c|c|c|}
\hline Authors & Study design & Intervention & Control & Main findings & Comments \\
\hline $\begin{array}{l}\text { Wang } \\
\text { et al. }{ }^{[4]}\end{array}$ & $\begin{array}{l}\text { RCT: } \\
\text { Remdesivir } \\
\text { versus placebo } \\
\text { in 2:1 ratio }\end{array}$ & $\begin{array}{l}\text { Remdesivir } 200 \mathrm{mg} \text { on day } 1 \text {, } \\
100 \mathrm{mg} \text { /day for } 9 \text { more days }\end{array}$ & Placebo & $\begin{array}{l}\text { No difference in time to clinical } \\
\text { improvement. More rapid } \\
\text { improvement with remdesivir in } \\
\text { patients with } 10 \text { days or less of illness }\end{array}$ & $\begin{array}{l}\text { Study was stopped prematurely as } \\
\text { enrollment ceased due control of } \\
\text { the outbreak. Statistical power was } \\
\text { not achieved }\end{array}$ \\
\hline $\begin{array}{l}\text { Beigel } \\
\text { et al. } .^{[5]}\end{array}$ & $\mathrm{RCT}$ & $\begin{array}{l}\text { Remdesivir } 200 \mathrm{mg} \text { on day } 1 \text {, } \\
100 \mathrm{mg} / \text { day for } 9 \text { more days }\end{array}$ & Placebo & $\begin{array}{l}\text { More rapid recovery with remdesivir. } \\
\text { Median recovery time; } 11 \text { versus } \\
15 \text { days; statistically significant. No } \\
\text { difference in } 14 \text { days mortality }\end{array}$ & $\begin{array}{l}\text { Trend towards improved survival } \\
\text { with remdesivir }\end{array}$ \\
\hline $\begin{array}{l}\text { Spinner } \\
\text { et al. }{ }^{[6]}\end{array}$ & $\begin{array}{l}\text { RCT: } \\
\text { Remdesivir } \\
\text { for } 5 \text { or } \\
10 \text { days or } \\
\text { standard care } \\
\text { in } 1: 1: 1 \text { ratio }\end{array}$ & $\begin{array}{l}\text { Remdesivir } 200 \mathrm{mg} \text { on day } \\
1,100 \mathrm{mg} / \text { day for } 4 \text { (total } \\
\text { duration: } 5 \text { days) or } 9 \text { days } \\
\text { (total duration: } 10 \text { days) }\end{array}$ & $\begin{array}{l}\text { Standard } \\
\text { care }(200 \\
\text { patients })\end{array}$ & $\begin{array}{l}\text { More favorable clinical status on day } \\
11 \text { with } 5 \text { days remdesivir compared } \\
\text { to the standard care arm. No } \\
\text { difference in clinical status between } \\
\text { the } 10 \text { days remdesivir group and } \\
\text { standard care }\end{array}$ & $\begin{array}{l}\text { A } 5 \text { days course of remdesivir may } \\
\text { be adequate compared to a } 10 \text { days } \\
\text { course }\end{array}$ \\
\hline $\begin{array}{l}\text { Horby } \\
\text { et al. } .^{[2]}\end{array}$ & RCT & $\begin{array}{l}\text { Dexamethasone } 6 \mathrm{mg} / \mathrm{day} \text {, } \\
\text { orally or intravenously }\end{array}$ & $\begin{array}{l}\text { Standard } \\
\text { care }\end{array}$ & $\begin{array}{l}\text { Significantly lower } 28 \text { days mortality } \\
\text { with dexamethasone ( } 22.9 \text { vs. } 25.7 \text {; } \\
\mathrm{P}<0.001 \text { ). Mortality lower in patients } \\
\text { who received invasive mechanical } \\
\text { ventilation and those requiring } \\
\text { oxygen without invasive ventilation }\end{array}$ & $\begin{array}{l}\text { No difference in mortality in } \\
\text { patients who did not require } \\
\text { supplemental oxygen }\end{array}$ \\
\hline $\begin{array}{l}\text { Gordon } \\
\text { et al. } .^{[19]}\end{array}$ & $\mathrm{RCT}$ & $\begin{array}{l}\text { Tocilizumab } 8 \mathrm{mg} / \mathrm{kg} \\
\text { intravenously }\end{array}$ & $\begin{array}{l}\text { Standard } \\
\text { care }\end{array}$ & $\begin{array}{l}\text { More organ support-free days, earlier } \\
\text { discharge from hospital, and reduced } \\
\text { in-hospital mortality with tocilizumab }\end{array}$ & $\begin{array}{l}\text { Combined with corticosteroids in } \\
92.7 \% \text { patients in the tocilizumab } \\
\text { arm and } 93.9 \% \text { patients in the } \\
\text { control arm }\end{array}$ \\
\hline $\begin{array}{l}\text { Group } \\
\text { et al. } .^{[19]}\end{array}$ & $\mathrm{RCT}$ & $\begin{array}{l}\text { Tocilizumab } 400-800 \mathrm{mg} \\
\text { intravenously; second dose in } \\
12-24 \mathrm{~h} \text { if no improvement }\end{array}$ & $\begin{array}{l}\text { Standard } \\
\text { care }\end{array}$ & $\begin{array}{l}\text { Lower } 28 \text { days all-cause mortality } \\
\text { with tocilizumab }\end{array}$ & $\begin{array}{l}\text { Mortality benefit confined to } \\
\text { patients who received tocilizumab } \\
\text { in combination with corticosteroids }\end{array}$ \\
\hline $\begin{array}{l}\text { Kalil } \\
\text { et al. } .^{[7]}\end{array}$ & $\mathrm{RCT}$ & $\begin{array}{l}\text { Baricitinib } 4 \mathrm{mg} \text { daily for } 14 \\
\text { days or until hospital discharge, } \\
\text { combined with remdesivir }\end{array}$ & Placebo & $\begin{array}{l}\text { Median time to recovery significantly } \\
\text { lower with baricitinib }\end{array}$ & $\begin{array}{l}\text { Particularly beneficial in patients on } \\
\text { high-flow oxygen or noninvasive } \\
\text { ventilation at enrolment }\end{array}$ \\
\hline
\end{tabular}


evolve. The cornerstone of management continues to be based on supportive care, with the possible use of pharmacological agents in patients with more severe illness.

The antiviral agent, remdesivir, may help shorten the duration of illness; however, it may not improve survival in patients with life-threatening illness. Among patients who are hypoxic and require supplemental oxygen or mechanical ventilation, low-dose dexamethasone has been shown to improve survival. Convalescent plasma has not lived up to the promise it held initially, with recent RCTs demonstrating a lack of benefit. Cytokine inhibitors including tocilizumab and miscellaneous immunomodulatory agents need further evaluation in improving outcomes in COVID-19.

\section{Financial support and sponsorship}

Nil.

\section{Conflicts of interest}

There are no conflicts of interest.

\section{ReFERENCES}

1. Mulangu S, Dodd LE, Davey RT Jr., Tshiani Mbaya O, Proschan M, Mukadi D, et al. A randomized, controlled trial of ebola virus disease therapeutics. N Engl J Med 2019;381:2293-303.

2. Holshue ML, DeBolt C, Lindquist S, Lofy KH, Wiesman J, Bruce H, et al. First case of 2019 novel coronavirus in the United States. N Engl J Med 2020;382:929-36.

3. NIH Clinical Trial of Remdesivir to Treat COVID-19 Begins. National Institutes of Health (NIH); Published February 25, 2020. Available from: https://www.nih.gov/news-events/news-releases/nih-clinical-trial -remdesivir-treat-covid-19-begins. [Last accessed on 2020 Sep 13].

4. Beigel JH, Tomashek KM, Dodd LE, Mehta AK, Zingman BS, Kalil AC, et al. Remdesivir for the treatment of Covid-19 - Preliminary report. N Engl J Med 2020; 383:1813-26. [doi: 10.1056/NEJMoa2007764].

5. Spinner CD, Gottlieb RL, Criner GJ, Lopez JRA, Cattelan AM, Viladomiu AS, et al. Effect of Remdesivir vs Standard Care on Clinical Status at 11 Days in Patients With Moderate COVID-19: A Randomized Clinical Trial. JAMA. 2020;324:1048-57.

6. WHO Solidarity Trial Consortium, Pan H, Peto R, Henao-Restrepo AM, Preziosi MP, Sathiyamoorthy V, et al. Repurposed antiviral drugs for Covid-19-Interim WHO solidarity trial results. N Engl J Med 2021;384:497-511.

7. Kalil AC, Patterson TF, Mehta AK, Tomashek KM, Wolfe CR, Ghazaryan V, et al. Baricitinib plus remdesivir for hospitalized adults with Covid-19. N Engl J Med 2021;384:795-807.

8. Ivashchenko AA, Dmitriev KA, Vostokova NV, Azarova VN, Blinow AA, Egorova AN, et al. AVIFAVIR for Treatment of Patients with Moderate COVID-19: Interim Results of a Phase II/III Multicenter Randomized Clinical Trial. Clin Infect Dis. 2020 Aug 9:ciaa1176. doi: 10.1093/cid/ciaa1176. Epub ahead of print. PMID: 32770240; PMCID: PMC7454388.

9. Control of COVID-19 Outbreaks in Long Term Care-Full Text View-ClinicalTrials.gov. Available from: https://clinicaltrials.gov/ct2/ show/NCT04448119. [Last accessed on 2020 Sep 13].

10. Caly L, Druce JD, Catton MG, Jans DA, Wagstaff KM. The FDA-approved drug ivermectin inhibits the replication of SARS-CoV-2 in vitro. Antiviral Res 2020;178:104787.

11. Momekov G, Momekova D. Ivermectin as a potential COVID-19 treatment from the pharmacokinetic point of view: Antiviral levels are not likely attainable with known dosing regimens. Biotechnol Biotechnol Equip 2020;34:469-74. [doi: 10.1080/13102818.2020.1775118].

12. López-Medina E, López P, Hurtado IC, Davalos DM, Ramirez O, Martinez E, et al. Effect of Ivermectin on Time to Resolution of Symptoms Among Adults With Mild COVID-19: A Randomized Clinical Trial. JAMA. 2021;325:1426-35.

13. Yao X, Ye F, Zhang M, Cui C, Huang B, Niu P, et al. In vitro antiviral activity and projection of optimized dosing design of hydroxychloroquine for the treatment of severe acute respiratory syndrome coronavirus 2 (SARS-CoV-2). Clin Infect Dis 2020;71:732-9.

14. No Clinical Benefit from Use of Hydroxychloroquine in Hospitalised Patients with COVID-19 - RECOVERY Trial. Available from: https:// www.recoverytrial.net/news/statement-from-the-chief-investigators-of -the-randomised-evaluation-of-covid-19-therapy-recovery-trial-on-hyd roxychloroquine-5-june-2020-no-clinical-benefit-from-use-of-hydroxy chloroquine-in-hospitalised-patients-with-covid-19. [Last accessed on 2020 Sep 13].

15. Tang W, Cao Z, Han M, Wang Z, Chen J, Sun W, et al. Hydroxychloroquine in patients with mainly mild to moderate coronavirus disease 2019: Open label, randomised controlled trial. BMJ 2020;369:m1849. [doi: 10.1136/bmj.m1849].

16. Chacko J, Brar G, Premkumar R. Hydroxychloroquine in COVID-19: An updated systematic review with meta-analysis. medRxiv 2020.05.14.20101774; doi: https://doi.org/10.1101/2020.05.14.20101774.

17. Kashour Z, Riaz M, Garbati MA, AlDosary O, Tlayjeh H, Gerberi D, et al. Efficacy of chloroquine or hydroxychloroquine in COVID-19 patients: A systematic review and meta-analysis. J Antimicrob Chemother 2021;76:30-42.

18. Roche Provides an Update on the Phase III COVACTA Trial of Actemra/ RoActemra in Hospitalised Patients with Severe COVID-19 Associated Pneumonia. Available from: https://www.roche.com/investors/updates/ inv-update-2020-07-29.htm. [Last accessed on 2020 Sep 14].

19. REMAP-CAP Investigators, Gordon AC, Mouncey PR, Al-Beidh F, Rowan KM, Nichol AD, et al. Interleukin-6 receptor antagonists in critically ill patients with Covid-19. N Engl J Med 2021. DOI: 10.1056/ NEJMoa2100433.

20. Horby PW, Pessoa-Amorim G, Peto L, Brightling CE, Sarkar R, Thomas, et al. RECOVERY Collaborative Group. Tocilizumab in patients admitted to hospital with COVID-19 (RECOVERY): preliminary results of a randomised, controlled, open-label, platform trial. medRxiv 2021.02.11.21249258; doi: https://doi.org/10.1101/2021.02.11.21249258.

21. Cavalli G, De Luca G, Campochiaro C, Della-Torre E, Ripa M, Canetti D, et al. Interleukin-1 blockade with high-dose anakinra in patients with COVID-19, acute respiratory distress syndrome, and hyperinflammation: A retrospective cohort study. Lancet Rheumatol 2020;2:e325-31.

22. Huet T, Beaussier H, Voisin O, Jouveshomme S, Dauriat G, Lazareth I, et al. Anakinra for severe forms of COVID-19: A cohort study. Lancet Rheumatol 2020;2:e393-400.

23. Randomised Evaluation of COVID-19 Therapy-Full Text View-ClinicalTrials.gov. Available from: https://clinicaltrials.gov/ct2/ show/NCT04381936. [Last accessed on 2020 Sep 13].

24. Horby P, Lim WS, Emberson JR, Mafham M, Bell JL, Linsell L, et al. RECOVERY Collaborative Group. Dexamethasone in Hospitalized Patients with Covid-19. N Engl J Med. 2021;384:693-704. doi: 10.1056/ NEJMoa2021436. Epub 2020 Jul 17. PMID: 32678530; PMCID: PMC7383595.

25. Dequin P, Heming N, Meziani F, Plantefeve G, Voiriot G, Badie J, et al. Effect of Hydrocortisone on 21-Day Mortality or Respiratory Support Among Critically Ill Patients With COVID-19: A Randomized Clinical Trial. JAMA. 2020;324:1298-306.

26. Li L, Zhang W, Hu Y, Tong X, Zheng S, Yang J, et al. Effect of convalescent plasma therapy on time to clinical improvement in patients with severe and life-threatening COVID-19: A randomized clinical trial. JAMA 2020;324:460-70.

27. Effect of Convalescent Plasma on Mortality among Hospitalized Patients with COVID-19: Initial Three-Month Experience Joyner MJ, Senefeld JW, Klassen SA, Mills JR, Johnson PW, Theel ES, et al. the US EAP COVID-19 Plasma Consortium. medRxiv 2020.08.12.20169359. doi: https://doi.org/10.1101/2020.08.12.20169359.

28. Agarwal A, Mukherjee A, Kumar G, Chatterjee P, Bhatnagar T, Malhotra $\mathrm{P}$, et al. Convalescent plasma in the management of moderate covid-19 in adults in India: open label phase II multicentre randomised controlled trial (PLACID Trial) BMJ 2020;371:m3939 doi:10.1136/bmj.m3939.

29. Simonovich VA, Burgos Pratx LD, Scibona P, Beruto MV, Vallone MG, Vázquez C, et al. A randomized trial of convalescent plasma in Covid-19 severe pneumonia. N Engl J Med 2021;384:619-29. 